PENELITIAN

\title{
Peran Deksmedetomidin Sebagai Protektor Otak Yang Dinilai Dengan Kadar II- 6 Dan Cox-2 Pada Tikus Model Cedera Otak Traumatika
}

\section{The Role Of Dexmedetomidine As Brain Protector Assessed by Il-6 And Cox-2 Concentration In Rat Model Of Traumatic Brain Injury}

\author{
Moh.Sofyan Harahap $₫ *$, A. Himendra Wargahadibrata**, Tatang Bisri**, Nancy M \\ Rehatta*** \\ * Bagian Anestesi dan Terapi Intensif Fakultas Kedokteran Universitas Diponegoro/ RSUP Dr. Kariadi Semarang. \\ **Bag.Anestesiologi dan Terapi Intensif, Fak.Kedokteran Universitas Padjadjaran/RS. dr. Hasan Sadikin, Bandung. \\ ***Bag.Anestesiologi dan Reanimasi, Fak. Kedokteran Universitas Airlangga/RSUD dr. Sutomo, Surabaya. \\ *Korespondensi/ Correspondence: dr. Sofyan
}

\section{ABSTRACT}

Background : Brain protection is one of the important issue in brain trauma management, to prevent secondary brain injury. There are basic method and pharmacologic method in brain protection. Many studies over the world perform to find best drugs for brain protection, but so far the result still inconsistent.

Objective: The objective of this study is to evaluate the role of dexmedetomidine as brain protector based on IL-6 and COX-2 concentration.

Methods: A laboratory experimental study with randomized control trial design had been conducted on 24 male, wistar rat, about 3 month old, to receive artificial brain trauma in standard methode, to get moderate brain injury. After the approval from ethical committee, wistar rat divided into three group, $\mathrm{Kl}$ goup, $n=8,(\mathrm{NaCl})$, P group $n=8$, (treatment) and $K 2$ group $=8$, (control). Rat anesthesied with ketamin $80 \mathrm{mg}$ / $\lg B W$ intra peritoneally, get blood sample for ELISA analysis, followed by craniectomy for artificial brain trauma only for group $K 1$ and $P$, after skin stitch rat of group $K 1$ receive saline intra peritoneal, and group $P$ get dexmedetomidine $60 \mu \mathrm{gr} /$ $\mathrm{kgBW}$. K2 group as control group were not received any trauma nor medication. Dexmedetomidine or saline was given serially at 3 hour, 12 hour and 24 hour after trauma. Next Blood sampling taken at 12 hour and 24 hour after trauma. Data were then analyzed with ANOVA and Friedman for group and Spearman analysis for correlation.

Result: IL-6 concentration in K1 goup increase significantly 12 and 24 hours after

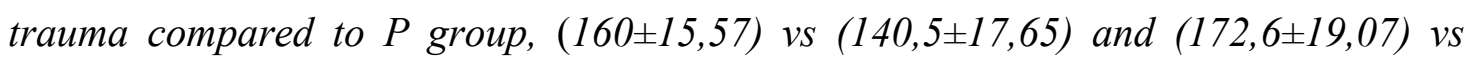
$(124,2 \pm 23,6)$. COX-2 concentration in K1 group increase significantly 12 and 24 hours after trauma compared to P group, $(1491,41 \pm 341)$ vs $(803,62 \pm 215,73)$ and $(1048,45 \pm 170,43)$ vs $(588,93 \pm 198,57)$. COX-2 concentration describe inflammation 
process. Spearman's analisys showed positive correlation between IL-6 and COX-2 $(\rho=0,71)$, in K1 group12 hour after trauma.

Conclusion:Dexmedetomidine has brain protection effect through decreasing of IL-6 and COX-2 concentration, and there are positive correlation between IL-6 and COX-2 concentration.

Keywords : brain protection, dexmedetomidine, IL-6, COX-2

\begin{abstract}
ABSTRAK
Latar belakang: Proteksi otak sangat penting dalam penanganan cedera kepala sehari hari, agar tidak terjadi cedera sekunder. Proteksi otak terdiri dari metode dasar dan farmakologik yaitu dengan menggunakan obar-obatan. Sampai saat ini belum ada hasil proteksi otak yang konsisten dari berbagai metode farmakologi, sehingga masih terus menjadi bahan kajian.
\end{abstract}

Tujuan : Penelitian ini untuk mengetahui peran deksmedetomidin sebagai protektor otak yang dinilai dengan kadar IL-6 dan COX-2.

Metode : Penelitian eksperimental di laboratorium dengan rancangan acak terkontrol, dilakukan pada 24 tikus wistar jantan, usia sekitar 3 bulan, kondisi aktif, yang mendapat perlakuan cedera kepala buatan derajat sedang. Setelah mendapat persetujuan komite etik, hewan coba dibagi dalam 3 kelompok secara random yaitu kelompok $\mathrm{K} 1(\mathrm{NaCl})(\mathrm{n}=8)$, kelompok $\mathrm{P}$ (deksmedetomidin) $(\mathrm{n}=8)$ dan kelompok $\mathrm{K} 2$ (kontrol) ( $\mathrm{n}=8)$, kemudian dilakukan anestesi dengan Ketamin $80 \mathrm{mg} / \mathrm{kgBB}$ ip dan diambil sampel darah, selanjutnya kelompok $\mathrm{K} 1$ dan kelompok $\mathrm{P}$ dilakukan kraniektomi dan diberi trauma diikuti dengan pemberian deksmedetomidin $60 \mu \mathrm{gr} /$ kgBB ip untuk kelompok $\mathrm{P}$ dan $\mathrm{NaCl}$ dengan volume dan cara sama untuk kelompok K1. Kelompok K2 tidak dilakukan cedera dan tidak mendapat terapi apapun. Pemberian deksmedetomidin atau $\mathrm{NaCl}$ diulang pada jam ke-3, ke-12 dan ke-24, pengambilan sampel darah berikutnya untuk pemeriksaan dengan metode ELISA dilakukan pada jam ke-12 dan jam ke-24. Data yang diperoleh kemudian dianalisis dengan uji ANOVA dan Friedman serta uji korelasi Spearman.

Hasil: Kadar IL-6 pada kelompok K1 meningkat secara bermakna dibanding kelompok P, pada 12 jam dan 24 jam pasca trauma. $(160 \pm 15,57)$ vs $(140,5 \pm 17,65)$ dan $(172,6 \pm 19,07)$ vs $(124,2 \pm 23,6)$. Sedangkan Kadar COX-2 pada kelompok K1 meningkat secara bermakna dibanding kelompok $\mathrm{P}$ pada 12 jam dan 24 jam pasca trauma. $(1491,41 \pm 341)$ vs $(803,62 \pm 215,73)$ dan $(1048,45 \pm 170,43)$ vs $(588,93 \pm 198,57)$. Kadar COX-2 menunjukkan proses inflamasi yang terjadi. Analisis Spearman's 
menunjukkan adanya korelasi positif antara IL-6 dan COX-2 $(\rho=0,71)$, yang terjadi pada 12 jam pasca trauma pada kelompok yang mendapat $\mathrm{NaCl}$.

Simpulan: Deksmedetomidin mempunyai peran sebagai protektor otak dengan menurunkan kadar IL-6 dan COX-2. Ada korelasi positif pada perubahan kadar antara IL-6 dan COX-2 setelah trauma.

Kata kunci: Proteksi otak, Deksmedetomidin, IL-6, COX-2.

\section{PENDAHULUAN}

Telah diketahui bahwa akibat cedera kepala akan terjadi berbagai respons patofisiologi antara lain pelepasan sitokin, suatu mediator utama pada awal proses inflamasi terhadap trauma. Ada beberapa jenis sitokin yang telah diteliti pada cedera kepala, antara lain sitokin pro inflamasi misalnya: interleukin-1 (IL-1), IL-6, IL8 , dan tumor necrosis factor- $\alpha$ (TNFa). ${ }^{1,2}$

Interleukin-6 dan TNF- $\alpha$ dilepaskan setelah trauma kepala, dan pada penderita dengan GCS kurang dari 8, menunjukkan kadar IL-6 yang lebih tinggi. Sitokin yang dilepaskan setelah cedera kepala traumatika akan merangsang pembentukan asam arakidonat yang dengan bantuan COX2 akan dirubah menjadi prostaglandin yang menunjukkan proses inflamasi, semua ini berperan pada terjadinya cedera sekunder. ${ }^{3,4}$

Cedera kepala akan diikuti dengan pelepasan norepinefrin yang akan meningkatkan sitokin pro inflamasi seperti IL-1, IL-6 dan TNF- $\alpha$, selain itu, stress karena trauma akan mengaktivasi aksis Hipotalamus
Hipofisis Adrenal (aksis HHA), peningkatan aktivitas aksis ini ditandai dengan meningkatnya kortisol, dan adanya inflamasi ditandai dengan peningkatan IL-6 dan COX-2. Proses ini menjelaskan adanya hubungan antara sistem neuroendokrin dengan sistem imun, dan inflamasi adalah salah satu mekanisme yang berperan dalam memperberat cedera otak. 5,6

Deksmedetomidin merupakan $\alpha 2$ agonis generasi kedua yang sangat selektif untuk reseptor adrenergik $\alpha 2$ (rasio ikatannya 1600 : 1 untuk $\alpha 2$ : $\alpha 1$, Kerja utama reseptor agonis $\alpha-2$ adalah menghambat pelepasan norepinefrin yang menyebabkan berkurangnya eksitasi pada sistem saraf pusat. Deksmedetomidin dapat menekan tonus system saraf simpatis baik sentral maupun perifer. Pada penelitian dengan hewan coba, dilaporkan bahwa selama kejadian iskemi deksmedetomidin akan menekan kadar norepinefrin sampai 95\% dibanding kontrol. ${ }^{3,7,8}$

Deksmedetomidin mempunyai efek proteksi otak yang telah diungkapkan dalam beberapa penelitian, karena deksmedetomidin mengurangi pelepasan Norepinefrin, mekanisme ini 
berhubungan dengan kemampuan proteksi otak dari deksmedetomidin. 9,10

Penelitian terdahulu telah mengkaji peran deksmedetomidin dalam neuroproteksi pada cedera otak melalui efek deksmedetomidin dalam mengurangi respons simpatis pasca trauma, bukan pada efek terhadap inflamasi. Penelitian ini akan mengkaji peran deksmedetomidin sebagai protektor otak dengan menilai kadar IL6 dan COX-2 pada tikus model cedera otak traumatika, yang merupakan kajian terhadap efek anti inflamasi.

\section{METODE}

Subjek adalah 24 ekor tikus jantan galur wistar usia kurang lebih 3 bulan, berat badan 250 gr- 350 gr. Tikus wistar berasal dari pusat pengembangbiakan hewan coba, Laboratorium Penelitian dan Pengujian Terpadu (LPPT) unit IV, UGM, Yogyakarta.

Setelah mendapat persetujuan tertulis dari Komite Etik Penelitian Kedokteran dan Kesehatan, tikus dibagi menjadi tiga kelompok masing-masing 8 (delapan) ekor: Kelompok K1: Kelompok kontrol positif. Tikus wistar yang mendapat $\mathrm{NaCl} \quad 0,9 \%$ ip (intra peritoneal) pasca trauma.

Kelompok P : Kelompok perlakuan. Mendapat deksmedetomidin $60 \mu \mathrm{gr} / \mathrm{kg}$ ip (intra peritoneal) pasca trauma. Kelompok K2: Kelompok kontrol negatif. Tidak mendapat deksmedetomidin dan tidak mendapat trauma, berfungsi sebagai rujukan nilai normal parameter biokimia yang diamati.

Tikus dilakukan adaptasi selama 2 minggu dengan standar pemeliharaan hewan coba. Pada kelompok K1 dan P dilakukan cedera otak dengan beban 2,5 gr berupa besi bulat, yang dijatuhkan langsung pada duramater dari ketinggian $25 \mathrm{~cm}$ setelah dilakukan kraniektomi. Selanjutnya masingmasing kelompok mendapat obat yang sesuai secara intra peritoneal pada saat: setelah luka dijahit, 3 jam, 12 jam dan 24 jam setelah trauma. Pengukuran laju nadi, laju nafas, suhu dan saturasi oksigen dilakukan sebelum cedera, setelah luka dijahit selanjutnya pada 3 jam, 12 jam dan 24 jam pasca cedera. Pemeriksaan kortisol, IL-6 dan COX-2 dilakukan sebelum cedera, 12 jam dan 24 jam setelah cedera otak melalui vena orbita.

Pemeriksaan kadar kortisol, IL-6 dan COX-2 dilakukan dengan metode ELISA menggunakan Mouse IL-6 ELISA BMS 603, Bender Med System, (Burlingame,USA) dan Cusabio Biotech untuk pemeriksaan COX-2.

\section{HASIL}

Data dasar yang meliputi berat badan, lama tindakan untuk membuat cedera kepala buatan, nadi, laju nafas, suhu dan saturasi pada ketiga kelompok, menunjukkan tidak ada perbedaan yang 
bermakna $(\mathrm{p}>0,05)$ antara tiga

kelompok. (Tabel. 1)

Tabel 2 dan tabel 3 menyajikan nilai rerata dan simpang baku nadi per menit dan laju nafas per menit selama pengamatan. Hasil uji statistik dengan Anova dan Friedman menunjukkan tidak ada perbedaan yang bermakna ( $p>0,05) \quad$ untuk masing-masing kelompok maupun diantara ketiga kelompok.

Tabel 4 menunjukkan nilai rerata dan simpang baku suhu selama pengamatan. Analisis Friedman tampak ada perbedaan suhu pada kelompok $\mathrm{P}$ (deksmedetomidin) yang bermakna $(p=0,018)$ antara sebelum dan 3 jam pasca trauma.

Tabel 5 menunjukkan nilai rerata dan simpang baku saturasi oksigen antara ketiga kelompok selama pengamatan. Hasil uji statistik dengan Anova dan Friedman menunjukkan perbedaan yang tidak bermakna $(p<0,05)$ pada variabel yang diamati.

Terdapat perbedaan bermakna ( $p<0,05)$ kadar IL-6 pada ketiga kelompok pada 12 jam dan 24 jam setelah trauma. Dari tabel 6 dan gambar 1 tampak bahwa kadar IL-6 pada kelompok $\mathrm{NaCl}$ lebih tinggi dari kelompok P (Deks) dan kelompok kontrol. Pengamatan untuk masingmasing kelompok menunjukkan bahwa pada kelompok $\mathrm{K} 1 \quad(\mathrm{NaCl})$ ada perbedaan yang bermakna pada kadar IL-6 sebelum trauma dan 12 jam serta 24 jam sesudah trauma. Sedangkan pada kelompok P (Deks) dan kelompok K2 (kontrol) tidak didapatkan perbedaan yang bermakna $(p>0,05)$ antara sebelum trauma dengan 12 jam dan 24 jam pasca trauma.

Perbedaan yang bermakna kadar IL-6 pada 12 jam dan 24 jam jika dilanjutkan dengan analisis post hoc diperoleh data perbedaan yang bermakna terjadi antara kelompok K1 dengan kelompok $\mathrm{P}$, kelompok $\mathrm{K} 1$ dengan kelp K2.

Terdapat perbedaan bermakna $(\mathrm{p}<0,05)$ kadar COX-2 diantara ketiga kelompok pada 12 jam setelah trauma dan 24 jam setelah trauma. Jika dianalisis Post Hoc tampak bahwa perbedaan bermakna pada 12 jam terjadi antara kelompok $\mathrm{K} 1$ dengan kelompok $\mathrm{P}$ dan antara kelompok K1 dengan kelompok K2. Dari gambar 2 dan tabel 7, tampak bahwa kadar COX2 pada kelompok $\mathrm{NaCl}$ lebih tinggi dari kelompok P (Deks) dan kelompok kontrol. Pengamatan pada masingmasing kelompok menunjukkan bahwa pada kelompok $\mathrm{K} 1 \quad(\mathrm{NaCl})$ ada perbedaan yang bermakna perubahan kadar COX-2 sebelum trauma dengan 12 jam dan 24 jam sesudah trauma. Sedangkan pada kelompok P (Deks) dan kelompok K2 (kontrol) tidak didapatkan perbedaan yang bermakna (p >0,05) antara sebelum trauma dengan 12 jam dan 24 jam pasca trauma.

Dari hasil pengamatan variabel kadar IL-6 dan COX-2 dilakukan uji 
Tabel 1. Karakteristik Umum Objek Penelitian Sebelum Perlakuan

\begin{tabular}{lccccccc}
\hline \multirow{1}{*}{ Variabel } & \multicolumn{2}{c}{$\begin{array}{c}\text { Kelompok K1 } \\
\text { (NaCl) }\end{array}$} & \multicolumn{2}{c}{$\begin{array}{c}\text { Kelompok P } \\
\text { (Deks) }\end{array}$} & \multicolumn{2}{c}{$\begin{array}{c}\text { Kelompok K2 } \\
\text { (Kontrol) }\end{array}$} & \multirow{2}{*}{$\begin{array}{c}\text { Nilaip } \\
\text { (Anova) }\end{array}$} \\
\cline { 2 - 6 } & Rerata & SB & Rerata & SB & Rerata & SB & \\
\hline BB (gram) & 282,38 & 12,070 & 282,63 & 13,384 & 280,75 & 10,754 & $\mathbf{0 , 9 4 5}$ \\
$\begin{array}{l}\text { Lama tindakan } \\
\text { (menit) }\end{array}$ & 18,25 & 1,488 & 18,38 & 1,188 & 18,13 & 1,727 & $\mathbf{0 , 9 4 5}$ \\
Nadi & 179,38 & 4,406 & 178,88 & 2,949 & 179,0 & 2,390 & $\mathbf{0 , 9 5 3}$ \\
Laju nafas & 59,75 & 1,982 & 59,75 & 1,982 & 59,75 & 1,982 & $\mathbf{1 , 0 0 0}$ \\
Suhu & 36,96 & 0,074 & 36,95 & 0,141 & 36,96 & 0,130 & $\mathbf{0 , 9 7 1}$ \\
Saturasi & 97,38 & 0,518 & 97,38 & 0,518 & 97,38 & 0,518 & $\mathbf{1 , 0 0 0}$ \\
& & & & & & &
\end{tabular}

$\mathrm{SB}=$ simpang baku

Tabel. 2 Nilai rerata dan simpang baku laju Nadi per menit selama pengamatan

\begin{tabular}{|c|c|c|c|c|c|c|c|}
\hline \multirow{3}{*}{$\begin{array}{c}\text { Waktu } \\
\text { pengamatan }\end{array}$} & \multicolumn{6}{|c|}{ Subjek penelitian } & \multirow{3}{*}{$\begin{array}{l}\text { Nilai } \mathrm{p} \\
\text { (Anova) }\end{array}$} \\
\hline & \multicolumn{2}{|c|}{$\begin{array}{l}\text { Kelompok K1 } \\
\qquad(\mathrm{NaCl})\end{array}$} & \multicolumn{2}{|c|}{$\begin{array}{c}\text { Kelompok P } \\
\text { (Deks) }\end{array}$} & \multicolumn{2}{|c|}{$\begin{array}{c}\text { Kelompok K2 } \\
\text { (kontrol) }\end{array}$} & \\
\hline & Rerata & SB & Rerata & SB & Rerata & SB & \\
\hline Pre trauma & 179,38 & 4,406 & 178,88 & 2,949 & 179,00 & 2,390 & $\mathbf{0 , 9 5 3}$ \\
\hline Post trauma & 179,50 & 3,742 & 178,63 & 1,768 & 178,88 & 1,727 & 0,787 \\
\hline Post 3 jam & 176,75 & 6,756 & 177,75 & 2,172 & 178,63 & 1,768 & 0,691 \\
\hline Post 12 jam & 179,25 & 2,375 & 176,75 & 2,605 & 179,75 & 2,493 & 0,056 \\
\hline Post 24 jam & 182,25 & 4,334 & 178,50 & 2,330 & 181,00 & 2,138 & 0,069 \\
\hline $\begin{array}{l}\text { Nilai }-p \\
\text { (Friedman) }\end{array}$ & \multicolumn{2}{|c|}{0,697} & \multicolumn{2}{|c|}{0,252} & \multicolumn{2}{|c|}{0,179} & -- \\
\hline
\end{tabular}

$\mathrm{SB}=$ simpang baku 
Tabel .3 Nilai rerata dan simpang baku laju nafas per menit selama pengamatan

\begin{tabular}{|c|c|c|c|c|c|c|c|}
\hline \multirow{3}{*}{$\begin{array}{c}\text { Waktu } \\
\text { pengamatan }\end{array}$} & \multicolumn{6}{|c|}{ Subjek penelitian } & \multirow{3}{*}{$\begin{array}{l}\text { Nilai-p } \\
\text { (Anova) }\end{array}$} \\
\hline & \multicolumn{2}{|c|}{$\begin{array}{l}\text { Kelompok K1 } \\
(\mathrm{NaCl})\end{array}$} & \multicolumn{2}{|c|}{$\begin{array}{c}\text { Kelompok P } \\
\text { (Deks) }\end{array}$} & \multicolumn{2}{|c|}{$\begin{array}{c}\text { Kelompok K2 } \\
\text { (Kontrol) }\end{array}$} & \\
\hline & Rerata & SB & Rerata & SB & Rerata & SB & \\
\hline Pre trauma & 59,75 & 1,982 & 59,75 & 1,982 & 59,75 & 1,982 & 1,000 \\
\hline Post trauma & 59,50 & 2,070 & 59,50 & 2,070 & 59,75 & 1,982 & 0,961 \\
\hline Post 3 jam & 59,75 & 2,915 & 59,25 & 4,132 & 60,50 & 2,330 & 0,739 \\
\hline Post 12 jam & 60,25 & 2,493 & 60,00 & 2,619 & 61,00 & 2,390 & 0,711 \\
\hline Post 24 jam & 62,75 & 3,196 & 60,25 & 2,493 & 62,00 & 4,408 & 0,351 \\
\hline $\begin{array}{l}\text { Nilai-p } \\
\text { (Friedman) }\end{array}$ & \multicolumn{2}{|c|}{0,169} & \multicolumn{2}{|c|}{$\mathbf{0 , 8 9 0}$} & \multicolumn{2}{|c|}{0,518} & -- \\
\hline
\end{tabular}

$\mathrm{SB}=$ simpang baku

Tabel. 4 Nilai rerata dan simpang baku suhu selama pengamatan.

\begin{tabular}{lccccccc}
\hline \multirow{2}{*}{$\begin{array}{l}\text { Waktu } \\
\text { pengamatan }\end{array}$} & \multicolumn{9}{c}{$\begin{array}{c}\text { Kelompok K1 } \\
(\mathrm{NaCl})\end{array}$} & \multicolumn{2}{c}{$\begin{array}{c}\text { Kelompok P } \\
\text { (Deks) }\end{array}$} & \multicolumn{2}{c}{$\begin{array}{c}\text { Kelompok K2 } \\
\text { (kontrol) }\end{array}$} & \multirow{2}{*}{$\begin{array}{c}\text { Nilai-p } \\
\text { (Anova) }\end{array}$} \\
\cline { 2 - 7 } & Rerata & SB & Rerata & SB & Rerata & SB & \\
\hline Pre trauma & 36,96 & 0,074 & 36,95 & 0,141 & 36,96 & 0,130 & $\mathbf{0 , 9 7 1}$ \\
Post trauma & 37,01 & 0,083 & 36,90 & 0,107 & 36,90 & 0,107 & $\mathbf{0 , 0 5 3}$ \\
Post 3 jam & 36,90 & 0,107 & 36,76 & 0,119 & 37,11 & 0,69 & $\mathbf{0 , 2 5 8}$ \\
Post 12 jam & 36,95 & 0,141 & 36,85 & 0,169 & 37,01 & 0,125 & $\mathbf{0 , 1 0 5}$ \\
Post 24 jam & 36,96 & 0,177 & 36,85 & 0,093 & 37,02 & 0,19 & $\mathbf{0 , 1 0 8}$ \\
\hline \multirow{2}{*}{$\begin{array}{l}\text { Nilai-p } \\
\text { (Friedman) }\end{array}$} & $\mathbf{0 , 3 6 4}$ & \multicolumn{7}{c}{$\mathbf{0 , 0 1 8}$} & & $\mathbf{0 , 9 5 8}$ & - \\
\hline
\end{tabular}

$\mathrm{SB}=$ simpang baku 
Tabel. 5 Nilai rerata dan simpang baku Saturasi selama pengamatan.

\begin{tabular}{|c|c|c|c|c|c|c|c|}
\hline \multirow{3}{*}{$\begin{array}{l}\text { Waktu } \\
\text { pengamatan }\end{array}$} & \multicolumn{6}{|c|}{ Subjek penelitian } & \multirow{3}{*}{$\begin{array}{l}\text { Nilai-p } \\
\text { (Anova) }\end{array}$} \\
\hline & \multicolumn{2}{|c|}{$\begin{array}{l}\text { Kelompok K1 } \\
\qquad(\mathrm{NaCl})\end{array}$} & \multicolumn{2}{|c|}{$\begin{array}{c}\text { Kelompok P } \\
\text { (Deks) }\end{array}$} & \multicolumn{2}{|c|}{$\begin{array}{l}\text { Kelompok K2 } \\
\text { (Kontrol) }\end{array}$} & \\
\hline & Rerata & SB & Rerata & SB & Rerata & SB & \\
\hline Pre trauma & 97,38 & 0,518 & 97,38 & 0,518 & 97,38 & 0,518 & 1,000 \\
\hline Post trauma & 97,13 & 0,641 & 97,25 & 0,463 & 97,13 & 0,641 & $\mathbf{0 , 8 8 7}$ \\
\hline Post 3 jam & 97,38 & 0,518 & 97,50 & 0,535 & 97,50 & 0,535 & 0,863 \\
\hline Post 12 jam & 97,13 & 0,354 & 97,38 & 0,518 & 97,50 & 0,535 & 0,296 \\
\hline Post 24 jam & 97,50 & 0,535 & 97,38 & 0,518 & 97,38 & 0,518 & 0,860 \\
\hline $\begin{array}{c}\text { Nilai-p } \\
\text { (Friedman) }\end{array}$ & \multicolumn{2}{|c|}{$\mathbf{0 , 5 5 6}$} & \multicolumn{2}{|c|}{0,910} & \multicolumn{2}{|c|}{$\mathbf{0 , 5 8 2}$} & -- \\
\hline
\end{tabular}

$\mathrm{SB}=$ simpang baku

Tabel. 6 Nilai rerata dan simpang baku kadar IL-6

\begin{tabular}{|c|c|c|c|c|c|c|c|c|}
\hline \multirow{3}{*}{ Waktu } & \multicolumn{6}{|c|}{ IL-6 ( $(\rho \mathrm{g} / \mathrm{ml})$} & \multirow{3}{*}{$\begin{array}{l}\text { Nilai- } p \\
\text { (Anova) }\end{array}$} & \multirow{3}{*}{ Post Hoc } \\
\hline & \multicolumn{2}{|c|}{$\begin{array}{c}\text { Kelp K1 } \\
(\mathrm{NaCl})\end{array}$} & \multicolumn{2}{|c|}{$\begin{array}{l}\text { Kelp P } \\
\text { (Deks) }\end{array}$} & \multicolumn{2}{|c|}{$\begin{array}{l}\text { Kelp K2 } \\
\text { (kontrol) }\end{array}$} & & \\
\hline & Rerata & SB & Rerata & SB & Rerata & SB & & \\
\hline Pra trauma & 133 & 24,071 & 143 & 16,937 & 137,5 & 29,135 & 0,708 & \\
\hline $12 \mathrm{jam}$ & 160 & 15,575 & 140,5 & 17,655 & 129,5 & 21,078 & $\mathbf{0 , 0 1 0}$ & $\begin{array}{l}\text { K1.P;K1- } \\
\text { K2 }\end{array}$ \\
\hline $24 \mathrm{jam}$ & 172,6 & 19,071 & 124,2 & 23,602 & 130,5 & 24,372 & 0,001 & $\begin{array}{l}\mathrm{K} 1 . \mathrm{P} ; \mathrm{K} 1- \\
\mathrm{K} 2\end{array}$ \\
\hline $\begin{array}{c}\text { Nilai- } p \\
\text { Friedman }\end{array}$ & \multicolumn{2}{|c|}{$\mathbf{0 , 0 0 0}$} & \multicolumn{2}{|c|}{0,206} & \multicolumn{2}{|c|}{0,908} & -- & \\
\hline
\end{tabular}

$\mathrm{SB}=$ simpang baku, Analisis Post Hoc 12 jam : K1-P (p=0,044), K1-K2 (p=0,003). Analisis Post Hoc 24 jam : K1-P (p=0,000), K1-K2 $(\mathrm{p}=0,001)$ 


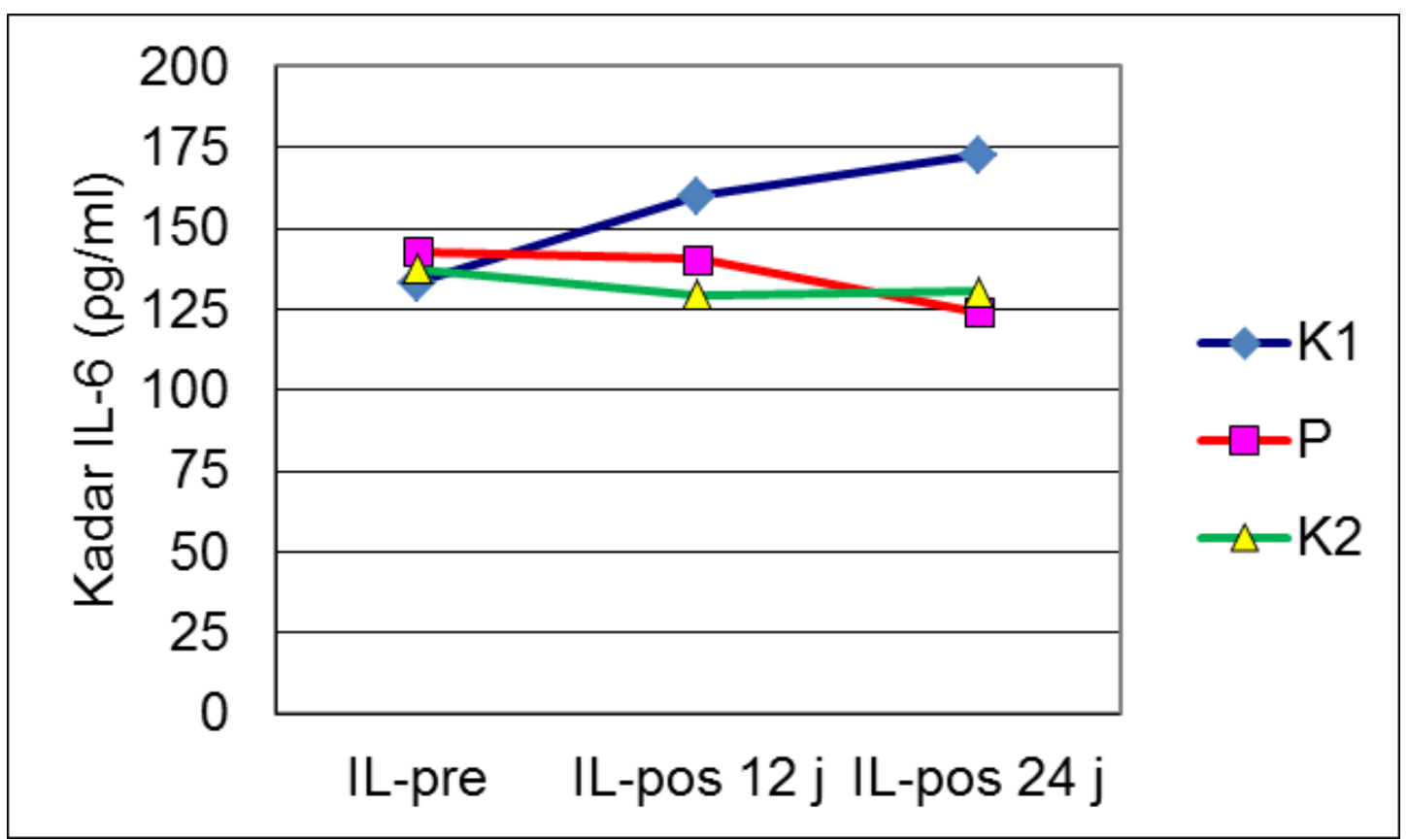

Gambar. 1 Grafik nilai rerata kadar IL-6 selama pengamatan

Tabel. 7 Nilai rerata dan simpang baku kadar COX-2

\begin{tabular}{|c|c|c|c|c|c|c|c|c|}
\hline \multirow{3}{*}{ Waktu } & \multicolumn{6}{|c|}{ COX-2 (pg/ml) } & \multirow{3}{*}{$\begin{array}{l}\text { Nilai } \\
\text { Anova }\end{array}$} & \multirow{3}{*}{ Post Hoc } \\
\hline & \multicolumn{2}{|c|}{$\begin{array}{c}\mathrm{K} 1 \\
(\mathrm{NaCl})\end{array}$} & \multicolumn{2}{|c|}{$\begin{array}{c}\mathrm{P} \\
\text { (Deks) }\end{array}$} & \multicolumn{2}{|c|}{$\begin{array}{c}\text { K2 } \\
\text { (Kontrol) }\end{array}$} & & \\
\hline & Rerata & SB & Rerata & SB & Rerata & SB & & \\
\hline $\begin{array}{l}\text { Pra } \\
\text { trauma }\end{array}$ & 847,54 & 370,53 & 849,03 & 614,1 & 748,67 & 198,57 & 0,867 & \\
\hline $12 \mathrm{jam}$ & 1491,41 & 341,33 & 803,62 & 215,73 & 563,18 & 319,43 & $\mathbf{0 , 0 0 0}$ & K1.P;K1.K2 \\
\hline 24 jam & 1048,45 & 170,43 & 588,93 & 198,57 & 751,91 & 305,79 & $\mathbf{0 , 0 0 3}$ & K1.P;K2.P \\
\hline $\begin{array}{l}\text { Nilai- } p \\
\text { Friedman }\end{array}$ & \multicolumn{2}{|c|}{0,044} & \multicolumn{2}{|c|}{$\mathbf{0 , 0 7 3}$} & \multicolumn{2}{|c|}{$\mathbf{0 , 0 9 3}$} & & \\
\hline
\end{tabular}


korelasi untuk melihat hubungan antara 2 variabel dan melihat korelasi diantara keduanya. Korelasi dianalisis berdasarkan perubahan yang terjadi setelah terpapar trauma, pada masing-masing kelompok. Perubahan yang terjadi setelah 12 jam pada kelompok K1 menunjukkan ada korelasi berdasarkan analisis Spearman's. Pada pada kelompok ini tidak ada pengaruh proteksi dari Deksmedetomidin, sehingga proses yang terjadi pasca trauma berjalan secara alamiah, dan tampak bahwa terjadi peningkatan kadar IL-6 yang seiring dengan peningkatan kadar COX-2 yang menggambarkan inflamasi. Data tersebut jika diuraikan lebih lanjut seperti tampak pada grafik dibawah, (gambar.3) dan persamaan regresinya tampak bahwa korelasi antara variabel ini merupakan korelasi positif.

\section{PEMBAHASAN}

Pada kelompok P terjadi penurunan suhu pada 3 jam setelah pemberian deksmedetomidin. Penurunan suhu ini disebabkan karena deksmedetomidin bersifat sedatif dan ansiolitik disamping juga menurunkan metabolisme, sehingga ada kecenderungan penurunan suhu tubuh.

Respons stres adalah istilah yang menggambarkan adanya perubahan hormonal dan metabolik setelah adanya trauma, hal ini merupakan bagian dari reaksi sistemik terhadap cedera yang merupakan gabungan reaksi endokrin, imun dan hematologi. Respons stres seperti suatu mekanisme untuk mempertahankan mahluk hidup agar tetap bertahan (survive) dengan mengkatabolisme karbohidrat, lemak dan protein, retensi cairan tubuh, sampai tubuh mengalami penyembuhan. Namun dalam praktek anestesi dan dunia kedokteran sekarang masih diragukan, apakah mahluk hidup masih harus menerima respons stres ini, untuk itu dalam praktek klinik diupayakan agar seseorang dapat bebas dari respons stres. ${ }^{13}$

Sitokin pertama yang dilepaskan setelah trauma/pembedahan adalah IL-1, TNF- $\alpha$ dan IL-6, reaksi diawali dengan pelepasan IL-1 dan TNF- $\alpha$ oleh makrofag dan monosit dari jaringan yang rusak, kemudian akan dilepaskan sitokin lain yaitu IL-6, sitokin utama yang berperan pada perubahan sistemik yang dikenal dengan respons fase akut. Aktivitas sitokin proinflamasi setelah terjadi trauma atau iskemi otak akan memperberat kerusakan otak karena adanya proses inflamasi, hal ini dapat berlanjut menjadi apoptosis dan cedera sekunder otak. Reaksi inflamasi yang meningkat dapat dilihat dari kadar COX-2, suatu enzim yang merubah asam arakidonat menjadi prostaglandin yang kemudian akan menimbulkan inflamasi. ${ }^{13}$

Mediator inflamasi dalam keadaan normal mempunyai kadar yang rendah, dan hanya sedikit mempengaruhi jaringan sehat tetapi setelah adanya cedera, sitokin proinflamasi akan segera meningkat dan bersama mediator lain berperan penting 
dalam proses inflamasi di sistem saraf pusat. Sitokin proinflamasi IL-6 sangat mempengaruhi ekspresi siklooksigenase (COX-2) di otak dan hal ini terjadi 3 jam setelah penyuntikan IL-6. ${ }^{17,18}$

Kadar IL-6 terus meningkat pasca trauma baik dibandingkan dengan kelompok lain maupun dalam kelompok $\mathrm{NaCl}$, hal ini menunjukkan respons sistemik terhadap trauma melalui aktivitas sitokin pro inflamasi. ${ }^{19}$

Peran sistim saraf otonom dalam sekresi IL-6 pada penelitian hewan adalah menstimulasi melalui mekanisme alfaadrenergik. Sehingga dapat dikatakan ada komunikasi dua arah antara sistem neuroendokrin (aksis HHA) dengan sisten neuroimun (sitokin). ${ }^{13,20-2}$

Deksmedetomidin

yang

mempunyai kemampuan menurunkan kadar norepinefrin melalui kerjanya di lokus sereleus, yang selanjutnya akan mengurangi aktivitas simpatis, efek ini merupakan suatu mekanisme sebagai protektor otak, dengan mekanisme ini pembentukan sitokin proinflamasi akan menurun sehingga dapat mengurangi inflamasi yang terjadi. ${ }^{6,19}$

Deksmedetomidin

telah

digunakan pada penelitian dengan model iskemi pada hewan coba dan menunjukkan kemampuannya mengurangi terjadinya nekrosis dan meningkatkan outcome neurologis. Hal ini disebabkan karena penurunan tonus simpatis / $\mathrm{m}$ enekan pelepasan noradrenalin. Dari penelitian lain diketahui bahwa aktivasi reseptor adrenergik oleh katekolamin tidak hanya mengakibatkan nekrosis sel tetapi juga kematian sel apoptotik, sehingga dapat disimpulkan bahwa deksmedetomidin mempunyai efek proteksi otak melalui mekanisma anti nekrotik dan anti apoptotik melalui kemampuannya mengatur protein pro dan anti apoptosis. 9

\section{Siklooksigenase-2}

(COX-2) adalah ensim yang memproduksi prostanoid dan berperan dalam toksisitas akibat inflamasi. Hasil pengamatan kadar COX-2 menunjukkan ada perbedaan dalam ketiga kelompok mulai dari 12 jam pasca trauma dan peningkatan COX-2 tampak lebih tinggi pada kelompok $\mathrm{NaCl}$ dibanding kelompok yang mendapat deksmedetomidin. Walaupun ada penurunan pada kelompok $\mathrm{NaCl}$ pada 24 jam namun kadarnya secara bermakna masih lebih tinggi dari kelompok deksmedetomidin.

Prostaglandin adalah mediator inflamasi yang diproduksi lewat metabolisme asam arakidonat dengan bantuan ensim siklooksigenase dan ensim prostaglandin sintase. Penelitian yang mengkaji efek inhibisi COX-2 sebagai protektor otak telah banyak dilakukan, dengan menggunakan preparat anti COX-2, sehingga jika deksmedetomidin juga dapat mencegah peningkatan COX-2 pasca cedera otak maka dapat sebagai bukti objektif efek neuroporotektor deksmedetomidin.${ }^{17}$

Terdapat korelasi positif antara 
IL-6 dan COX-2 pada kelompok yang mendapat $\mathrm{NaCl}$ pada 12 jam setelah cedera. Hasil korelasi positif antara dua variabel tersebut ( IL-6 dan COX-2) hanya terjadi pada kelompok K1 $(\mathrm{NaCl})$, hal ini disebabkan karena respons terhadap trauma terjadi tanpa dipengaruhi /dihambat oleh $\mathrm{NaCl}$, sedangkan pada kelompok $\mathrm{P}$ terjadi interaksi dengan deksmedetomidin yang mempengaruhi perubahan kadar ketiga variabel tersebut. Deksmedetomidin merupakan reseptor $\alpha-2$ agonis yang merupakan penghambat norepinefrin sehingga dapat mengurangi respons stres dan inflamasi pasca trauma/cedera, hal ini dapat mengurangi peningkatan IL-6 dan COX-2 sehingga jika dua hal ini dikorelasikan maka tidak didapat hasil korelasi yang kuat.

\section{SIMPULAN}

Pemberian deksmedetomidin
sebagai protektor otak lewat
mekanisme mengurangi aktivitas
katekolamin dengan menurunkan kadar
kortisol dan mengurangi proses
inflamasi dengan menurunkan kadar IL
-6 dan COX-2.

Deksmedetomidin dapat digunakan sebagai protektor otak dalam praktek klinik, dan masih terbuka penelitian untuk melihat efek deksmedetomidin untuk jangka lama, lebih dari 24 jam.

\section{DAFTAR PUSTAKA}

1. Sakabe T, Bendo AA. Anesthesia management of head trauma. Dalam: Newfield P, Cottrel JE, eds. Handbook of Neuroanesthesia edisi 4. Philadelphia: Lippincott Williams \& Wilkins; 2007.h. 93-4.

2. Tolias CM, Bullock MR. Critical appraisal of neuroprotection trials in head injury: what have we learned ?. The Journal of American Society for Experimental Neuro therapeutics 2004;1(1):71-5.

3. Quiney N, Cooper R, Stone ham M. Pain after cranioromy: a time for reappraisal ?. Br J Neurosurg 1996 ;10: 295.

4. Bhatia P. Dexmedetomidine: a new agent in anaesthesia and critical care practice. Dept.of Anaesthesiology \& Critical care. Dr. S.N Medical College, Jodhpur. 2002.

5. Liao J, Keiser J, Scales W, Kunkel S, Kluger MJ. Role of epinephrine in TNF and IL-6 production from isolated perfused rat liver. Am.J.Physiol 1995;37 (268) :8968.

6. Tobias JD. Dexmedetomidine in trauma anesthesiology and critical care. International trauma care (ITACCS) 2007;17 (1): 10-2 .

7. Sakic K, Zura M, Bogatin D. Neuroimmunomodulation by regional and general anesthesia. Priodicum Biologicum 2009;111(2):204-8.

8. Gertler R, Brown C, Mitchell D, Silvius EN. Dexmedetomidine: a novel sedative -analgesic agent. BUMC Proceeding 2001;14:13-7.

9. Engelhard $\mathrm{K}$, Werner $\mathrm{C}$, Kaspar $\mathrm{S}$, Mollenberg O, Blobner M, Bachl M, et al. 
Effect of the $\alpha-2$ agonist dexmedetomidine on cerebral neurotransmitter concentration during cerebral ischemia in rats. Anesthesiology 2002; 96(2): 234-6

10. Kuhmonen J, Pokorny J, Miettinen R, Haapalinna A, Jolkkonen J, Riekkinen P, et al. Neuroprotective effects of dexmedetomidine in the gerbil hippocampus after transient global ischemia. Anesthesiology 1997; 87(2): 347-50

11. Woolf PD. Hormonal responses to trauma, mini symposium articles. Critical Care Medicine 1992;20(2): 216-20.

12. King LR, Mc Lurin LR, Lewis HP, Knowles HC. Plasma cortisol level after head injury. Annals of Surgery.1970;(172) 6:976-82

13. Desborough JP. The stress response to trauma and injury. BJA 2000;85(1): 115-9.

14. Mustofa. Perlakuan Hewan Coba. Makalah pada Pelatihan Manajemen Hewan Coba. Lab. Penelitian dan Pengujian Terpadu, UGM. 7 Juli 2009. Yogyakarta.

15. Kloet ER, Sutanto W. The use of various animal models in the study of stress and stress-related phenomena. Laboratory Animals.1994;28:293-4.

16. Zhang XY, Zhou DF, Cao LY, Wu GY, Shen YC. Cortisol and cytokines in chronic and teratment-resistant patients with schizophrenia: association with psychopathology and response to antipsychot- ics. Neuropsychopharmacology. 2005:(30); 1532-4.

17. Lucas SM, Rothwell NJ, Gibson RM. The role if inflammation in CNS injury and disease. British Journal of Pharmacology.2006:147(51):232-4

18. Kagiwada K, Chida D, Sakatani T, Asano M, Nambu A, Kakuta $S$ et al. Interleukin (IL)-6, but not IL-1, induction in the brain downstream of cyclooxygenase- 2 is essential for the induction of febrile response aginst peripheral IL-1 $\alpha$. Endocrinology.2004;(11)145:5044-6.

19. Hoffman WE, Kochs E, Werner C, Thomas C, Albrecht RF. Dexmedetomidine improves neurologic outcome from incomplete ischemia in rat. Anesthesiology 1991;75:328-32.

20. Barone FC, Fewerstein BG. Inflammatory mediators and stroke : new opportunities for novel therapeutics. Journal of Cerebral Blood Flow and Metabolism 1999;19: 813-5.

21. Beattie MS. Inflamation and apoptosis: linked therapeutic targets in spinal cord injury. Trends in Molecular Medicine 2004; 10 (12):581-3

Turnbull AV, Rivier CL. Regulation of the hypothalamic-pituitary-adrenal axis by cytokines: action and mechanism of action. Phisiological reviews 1999;79(1):5-8 